\title{
Online Counselling Services: University Students' Perception
}

\author{
${ }^{1}$ Abu Shahim, M.R., ${ }^{1}$ Shaudi, L.S., ${ }^{2}$ Zainudin, Z.N., ${ }^{1}$ Kamarul, M.S. \\ ${ }^{1}$ University Malaysia Terengganu, Malaysia \\ ${ }^{2}$ University Putra Malaysia, Malaysia \\ m.radhi@umt.edu.my
}

Article History:Received:11 January 2021; Accepted: 27 February 2021; Published online: 5 April 2021

\begin{abstract}
Online counselling is no longer something new. It offers faster, safer and more practical in getting counselling services. This study aims to examine the perceptions of university students toward online counselling services which include aspects of attitude, knowledge and readiness at Universiti Malaysia Terengganu. This quantitative study has a total of 263 respondents from two different studies; social sciences and technology sciences. The Perceptions Toward Online Counseling Questionnaire is used as the instrument. The collected data were analysed using quantitative method. The data obtained were analysed with the help of Statistical Package for Social Science (SPSS) 23.0 for Windows. t-test analysis was used to analyse the data. The results showed that there was no significant difference in perceptions of attitude and readiness toward online counselling services based on the field of study. However, there is a significant difference in the perception of knowledge toward online counselling services based on the field of study. Therefore, the implications and recommendations for future research also discussed.
\end{abstract}

\section{Keywords: online counselling, counselling, perception.}

\subsection{INTRODUCTION}

According to Mohd Nor Mamat (2000), the present of the information era and digital has become common as a package (part and partial) in our daily life. Malaysia also involved in this technological revolution. Based on the statistics of Digital Report 2018 released by Hootsuit and We Are Social (2018), Internet users have increased to 25.08 million users, which represents 79 per cent of the population in Malaysia. It is nine per cent higher compared to the year 2017. It made Malaysia became the 9th most active country in the world on social media. According to Mastura, Zaida, Ramlan (2001), there are several platforms offered online counselling services in Malaysia. Among them are Befrienders, Pink Triangle, Teledera, Cancer On-Line, AIDS On-line, and others.

The technology and the Internet had transform counselling services which no longer limited to face-toface sessions, but online service has become another option. In addition, online counselling service is already available and been widely used when people are access to the internet (Tannous, 2017). According to Bloom (1998), counselling practitioners should not view modernity as a barrier but rather see the Internet as an effective facility. The use of computers seen as a catalyst in offering counselling services (Amla et al., 2015).

Online counselling has documented having the same benefits as face-to-face counselling (Barak, 2001). According to Derrig-Palumbo and Zeine (2005), some clients are comfortable with face-to-face therapy, while for some clients, online counselling is a bonus point for traditional therapy. However, some clients would only benefit from online therapy.

According to Kraus and Zack (2004); Larsen (1998), the objective of online counselling is providing consultancy services for those in need. It helps to identify and understand characteristics of capabilities and tendencies such as individual preparation skills. Offering e-counselling has opened up space and opportunities for those clients who stay in remote areas (Chester, A \& Glass, C, 2006; Hall, 2004; Robson \& Robson, 2000), clients who with disabilities in moving (Chester, A \& Glass, C, 2006; Robson \& Robson, 2000), clients with responsibilities at home for young children or parents (Chaudron 1998; Robson \& Robson, 2000), clients who are constantly moving on task and work factors (Lawrence, 1998; Murphy, 1998) as well as clients who need anonymity or do not want to identify by others (Hall, 2004; Robson \& Robson, 2000).

Hence, the counselling process is less limiting the freedom of the clients. The clients no longer need to be present in front of the counsellor, in the same room, and at the same time (Zainudin \& Mastura, 2006). In facts, according to Glueckauf (2002), clients can maintain their privacy by having therapy at home. Besides, it reduces the time for clients to rearrange their thoughts. The session can be continued as long as the client requires, it can be postponed or cancelled easily and clients can choose their preference counsellor (van de Luitgaarden, 2016).

According to literature studies, the perceptions involving aspects of attitude, knowledge, and readiness toward online counselling services are still lacking in Malaysia. Based on the research conducted by Mastura, Zainudin dan Ramlan (2001), almost $50 \%$ of the respondents are not aware of the existence of online 
counselling services in Malaysia. However, it is more than $50 \%$ of the respondents are willing to accept and participate in the online counselling session.

Thus, this study focuses on the perceptions of university students toward online counselling based on aspects of attitude, knowledge, and readiness. The field of study of the respondents will take into consideration to see how far it will affect the respondent's perception based on the aspects of attitude, knowledge, and readiness for online counselling services.

\subsection{LITERATURE REVIEW}

There are many past studies to make comparison of the effectiveness between online counseling sessions and face-to-face counseling sessions. Zainudin, Z.N, Yusop, Y.M, Hassan, S.A, Alias B.S. (2019) have showed that no relationship on personality traits towards cybertherapy approach. Liebert et al. (2006) have studied a group of 81 female clients who use online services to find out the therapeutic relationship and satisfaction variables reported by the client themselves. This study compared its findings with the findings with researches by McMurtry and Hudson (2000) and Busseri and Tyler (2003).

Liebert et al.(2006) found that the more respondents who spend time online, the more likely they are to use online counseling services. Researchers conclude that online clients are satisfied with online relationships and treatments, but that level of satisfaction is still low when compared to clients who have undergone traditional face-to-face counseling.

A study entitled Perceptions of online counseling among counselors in Malaysia (Zainah, Rohany \& Fatimah, 2010) is a preliminary research to explore the perception of counselors on the need for online counseling sessions or e-counseling. A total of 20 respondents were selected as subjects and data were collected using a questionnaire to study the use of e-counseling among counselors. The results of this study show that although respondents are seen as positive towards e-counseling, but they prefer face-to-face counseling to deliver their services to customers. However, researchers point out that it is important to note that more and more people will continue to see the internet as a source to deal with their mental health problems. Therefore, ongoing research in the use and application of online counseling will help shape the future of professional counseling.

Studies conducted by Wong, Bonn, Tam, \& Wong, (2018) show that overall, university students in Malaysia are less likely to give face-to-face counseling than online counseling, although both types of counseling are seen as positive. This feedback indicates that on average respondents are relatively open to receiving counseling services either online or in person.

According to Adel Tannous (2017), technology and the use of the internet have taken over the face-to-face counseling services and transformed them into online counseling. In a study that examined perceptions of online counseling among University of Jordan students found that respondents had a positive attitude and preferred online counseling as the best way to deal with problems in daily life. The results of this study also show that social media is the most effective medium in helping respondents to get counseling online and it has a huge impact on the lives of respondents.

Exploratory Studies on Client Perceptions of Internet Counseling and Therapeutic Relationships (Liebert, Archer, Munson and York, 2006) are among the studies of perceptions of online counseling that look at it from a demographic factor perspective. Sociodemography consists of 81 clients who use online counseling. The therapeutic relationship and satisfaction of online counseling therapy has been evaluated for comparison with previous studies involving traditional face counseling. Online clients are mostly women who are used to using the Internet and they enjoy the convenience and "anonymity" of this service.

Awabil and Akosah (2018) in their study which studied the attitude of university students in Ghana towards online counseling services stated that students show a positive attitude towards online counseling because their study specializes in attitude aspects. In fact, their current results are in line with the findings of Leibert, Archer, Munson and York (2006) who revealed that their clients provide good online counseling. Similarly, current findings agree with the results obtained by Finn and Bruce (2008) that clients have a generally positive attitude towards online counseling.

Lily Mastura, Zaida Nor and Ramlan (2001), conducted a study on the readiness of computer-savvy respondents to participate in e-counseling sessions. Their study, E-Counseling: Willingness to Participate, found that 50 $(52 \%)$ respondents were willing to accept or participate in e-counseling sessions. There are $39(41.9 \%)$ respondents who are not sure whether they can participate in the process or not while $5(5.4 \%)$ respondents rejected completely. 
So this article is intended to see the perception of students in one of universities in Malaysia to get clearer view.

\subsection{OBJECTIVES}

The research objectives for this research are:

3.1 Is there any significant difference in perception of attitude between students in the social sciences and technology sciences at Universiti Malaysia Terengganu towards online counseling services?

3.2 Is there any significant difference in perception of knowledge between students in the social sciences and technology sciences at Universiti Malaysia Terengganu towards online counseling services?

3.3 Is there any significant difference in perception of readiness between students in the social sciences and technology sciences at Universiti Malaysia Terengganu towards online counseling services?

\subsection{METHODOLOGY}

Quantitative approach was used to conduct this study. The researcher wishes to make a descriptive and inferential analysis. The independent variables for this study are two fields of studies in Universiti Malaysia Terengganu which are social science studies and technology science studies. While, the dependent variable for this study is the perception of attitude, knowledge, and readiness towards online counselling services among university students.

The instrument used in this study is Perceptions Toward Online Counseling Questionnaire. This questionnaire is built by the researcher based on the empirical research conducted by Zainah, Rohany dan Fatimah (2010), and Tannous (2017). The questionnaire is divided into three parts which are Section A: Respondent's biodata, Section B: experiences using online counselling, and Section C, D, and E are perception towards online counselling.

Respondents of this study are the final year students who study in the field of social science and field of technology science in Universiti Malaysia Terengganu. The students of social sciences studies selected from the program of Bachelor of Counselling and Bachelor of Management (Policy Studies). For the field of technology science studies, final year students of the program Bachelor of Computer Science (Software Engineering) and Bachelor of Computer Science with Maritime Informatics are selected as the respondents in this study.

\subsection{FINDINGS}

The perception of attitude between students in the social sciences and technology sciences at Universiti Malaysia Terengganu towards online counseling services

Referring to the findings of the first research question shows that there is no significant difference in the perception of attitudes towards online counseling services between students in the field of social science studies and the field of technology science studies at Universiti Malaysia Terengganu. However, based on the mean obtained, it is found that respondents from the field of social science studies have a more positive perception of attitude towards online counseling services compared to respondents from the technology science studies, although the differences are small.

The T-test analysis was used in this study to determine the differences between the two fields of study in perceptions of online counselling. The T-test is one of the statistical tests used to determine whether there is a significant difference in the mean value for two groups or two sets of data to be tested.

Table 1: T-test analysis of attitudes towards online counselling services based on field of study

\begin{tabular}{lllllll}
\hline Field of Study & $\mathrm{N}$ & Min & SD & $\mathrm{t}$ & $\mathrm{df}$ & Sig. \\
\hline Social Science & 132 & 3.411 & .528 & .498 & 261 & .619 \\
$\begin{array}{l}\text { Technology } \\
\text { Science }\end{array}$ & 131 & 3.372 & .745 & & \\
\hline
\end{tabular}

Table 1 showed the result of the T-test used to see the difference in perception of attitude between the students of social science $(\mathrm{M}=3.411, \mathrm{SD}=.528)$ and students of technology science $(\mathrm{M}=3.372, \mathrm{SD}=.745)$ toward online counselling services. Based on the result showed in the T-test, there is no significant difference in the perception of attitudes towards online counselling services between students in the field of social science studies and the field of technology science studies $(\mathrm{t}(261)=.498, \mathrm{p}>0.5)$. 
This findings supported Tannous (2017), which explores perceptions of online counseling among University of Jordan students and found that students have a positive attitude and high level of priority to use online counseling. The current results of this study are in line with the findings of Leibert, Archer, Munson and York (2006) who revealed that their clients receive online counseling well. Similarly, current findings agree with the results obtained by Finn and Bruce (2008) who stated that clients have a generally positive attitude towards online counseling.

Furthermore, the results of the study (Wong, Bonn, Tam, \& Wong, 2018) show that overall, university students in Malaysia have less face-to-face counseling than online counseling, although both types of counseling are seen as positive. This feedback indicates that on average respondents are relatively open to receiving counseling services either online or in person. Teh (2014) also stated that attitudes towards online counseling (compared to face-to-face counseling) are generally considered positive and the sample in his study showed openness to conduct counseling online. However, they still consider face-to-face counseling to be more effective than online counseling.

In conclusion, the results of this study are in line with the study of Tannous (2017), who stated that the most interesting finding in his study was that most samples showed positive attitudes and remarkable effects in their lives by using online counseling. The results of this study are also similar to the results of a study conducted by Zamani et.al. (2010) Bato \& Marcial, (2016). Thus, based on this study, the researcher can conclude that almost all respondents consisting of students from different fields of study at UMT show a positive attitude perception of online counseling services.

The perception of knowledge between students in the social sciences and technology sciences at Universiti Malaysia Terengganu towards online counseling services

The finding shows that there is a significant difference in the perception of knowledge towards online counseling services between students in social science studies and technology science studies at Universiti Malaysia Terengganu. Based on the mean obtained, it was found that there is a slight difference where respondents from technology science studies have a more positive perception of knowledge of online counseling services compared to respondents from the field of social science studies.

Table 2: T-test analysis of perceptions of knowledge towards online counselling services based on field of study

$\begin{array}{lllllll}\text { Field of Study } & \text { N } & \text { Min } & \text { SD } & \text { t } & \text { df } & \text { Sig. }\end{array}$

\begin{tabular}{lcccccc}
\hline $\begin{array}{l}\text { Social } \\
\text { Science }\end{array}$ & 132 & 3.342 & .556 & -2.072 & 261 & .039 \\
$\begin{array}{l}\text { Technology } \\
\text { Science }\end{array}$ & 131 & 3.530 & .878 & & \\
\hline
\end{tabular}

Table 2 showed the results of T-test used to determine the difference in perception of knowledge between the students of social science $(\mathrm{M}=3.342, \mathrm{SD}=.556)$ and students of Technology science $(\mathrm{M}=3.530, \mathrm{SD}=.878)$ on online counselling services. Based on the result showed in the table, there is a significant difference in the perception of knowledge towards online counselling services between students in the field of social science studies and the field of technology science studies $(\mathrm{t}(261)=-2.072, \mathrm{p}<.05)$.

The differences between these two fields of study indicates that university students have a good perception of knowledge of online counseling services despite different fields of study. The results of this study support the study (Tannous, 2017) which claims that students at the University of Jordan have a good knowledge of online counseling and respondents believe that online counseling is important because it is part of their way of dealing with everyday life problems. The findings of this study also indicate that the majority of respondents prefer to use online counseling to solve their personal and emotional problems. This is in line with the findings of Tannous (2017) study which explains that most respondents claim that not all problems can be solved by using online counseling which they consider that online counseling is more appropriate to solve time management issues, increase awareness, self-control and addiction. Almost all respondents also believe that online counseling is not suitable for severe problems such as mood or psychiatric disorders. 
Thus, the findings of this study have proven that the average student at UMT has excellent knowledge related to online counseling services. Even the respondents also know and are aware of the advantages and disadvantages of online counseling.

The perception of readiness between students in the social sciences and technology sciences at Universiti Malaysia Terengganu towards online counseling services

The finding shows that there is no significant difference in the perception of readiness for online counseling services between students in social science studies and technology science studies at Universiti Malaysia Terengganu. However, based on the mean obtained, it is found that there are some differences where respondents from the field of social science studies have a more positive perception of readiness for online counseling services compared to respondents from the field of technology science studies.

Table 3: T-test analysis of perceptions of readiness towards online counselling services based on the field of study

\begin{tabular}{lllllll}
\hline Field of Study & $\mathrm{N}$ & Min & SD & $\mathrm{t}$ & $\mathrm{df}$ & Sig. \\
\hline Social Science & 132 & 3.568 & .912 & 1.872 & 261 & .062 \\
$\begin{array}{l}\text { Technology } \\
\text { Science }\end{array}$ & 131 & 3.351 & .968 & & & \\
\hline
\end{tabular}

Table 3 Showed the results of T-test used to determine the difference in perception of readiness between the students of social science $(\mathrm{M}=3.568, \mathrm{SD}=.912)$ and students of technology science $(\mathrm{M}=3.351, \mathrm{SD}=.968)$ toward online counselling services. Based on the T-test result showed that there is no significant difference in the perception of readiness towards online counselling services between students in the field of social science studies and the field of technology science studies at Universiti Malaysia Terengganu. $(\mathrm{t}(261)=1.872, \mathrm{p}>.05)$.

The difference in perception of readiness between these two areas of study clearly shows that UMT students are willing and interested in using online counseling services. The findings of this study are in line with the findings of the study of Zainah Ahmad Zaman, et al. (2010), who stated that more than 50 percent of their respondents are interested in using online counseling and 85 percent are willing to accept and engage in online counseling.

Furthermore, Awabil and Akosah (2018) in their study which examined the attitude of university students in Ghana towards online counseling services stated that the relatively busy and busy daily schedule of students does not allow students to undergo face-to-face counseling sessions. Students are more interested in using the internet in dormitories to get online counseling services because it saves more time.

Accordingly, in Jordan, online counseling has become a more popular and viable form of counseling with the advancement of Information and Communication Technology (ICT). Thus, Jordan's available and convenient internet access through mobile and wireless networks makes it easy for clients to access counseling services online more quickly and at any time. (Tannous, 2017). In conclusion, the respondents are really interested and willing to use counseling services online because they are aware of the advantages of this service that may not be available in face-to-face counseling services.

\subsection{DISCUSSION}

In this study, T-test was the only analysis method used by the researcher to analyze the data. T-test is to determine differences in the perception of attitude, knowledge, and readiness on online counselling between the students in the field of social science studies and technology science studies at Universiti Malaysia Terengganu. Statistical Package for Social Sciences (SPSS) version 23.0 was the application used to analyze T-test.

Referring to the results of the finding showed that there is no significant difference in the perception of attitudes towards online counselling services between students in the field of social science studies and the field of technology science studies at Universiti Malaysia Terengganu. However, based on the mean score obtained, it can conclude as the students from the social science field have a more positive perception of attitude toward online counselling compare to the students from the field of technology science, although the differences are small.

The findings of the study showed that there is a significant difference in the perception of knowledge toward online counselling services between students in the field of social science studies and the field of technology science studies at Universiti Malaysia Terengganu. Based on the mean score obtained, it showed that 
there is a slight difference in the mean score between the variables. The students from the field of technology science studies have a better perception of knowledge toward online counselling services compare to the students in the field of social science studies (Rosnee et al., 2021).

The differences between the two study fields were insignificant. This showing the university students from different fields of study have a good perception of knowledge towards online counselling services. The result of this study has supported the empirical study done by Tannous (2017), which states that the students in the University of Jordon have good knowledge in online counselling and the respondents believe that online counselling is important because it is a part of their way to dealing with daily life issues.

Hence, the findings of this study have shown the average student in UMT has excellent knowledge related to online counselling services. Respondents knew and aware of the advantages and disadvantages of online counselling.

The next findings show that there is no significant difference in the perception of readiness towards online counselling between students in the field of social science studies and technology science studies in Universiti Malaysia Terengganu. However, according to the mean score obtained, it showed there is a small difference between the respondents from these two studies field. The results of the mean showed Social science studies respondents have more positive in the perception of readiness towards online counselling services compare to the technology science studies respondents.

In conclusion, the respondents are interested and ready to use online counselling services. This is due to they are aware of some advantages of online counselling may not be available in face-to-face counselling services.

\subsection{CONCLUSIONS}

The emergance of online counselling or known as E-counselling has provided better opportunities to the society for getting assistance through counselling services. This is because online services are more preferred by society where it less consume time and without dealing with other parties.

From the view of counselling and psychology, online counselling can be a solution for those clients who have difficulty dealing with the counsellor or who are uncomfortable sharing their problems and stories directly with counsellors. Therefore, this study is conducted to determine the perception of online counselling from the average university students who are an active internet user and always access to the internet.

\section{REFERENCES}

1. Abdul Ghani Shamsudin \& Norhashimi Saad (2000) 'Teknologi Web dan penyelesaian Permasalahan Sosial Pelajar'. Kertas kerja dibentang dalam Seminar Kebangsaan Hubungan Sekolah dengan Komuniti: Strategi Menangani Masalah Pelajar, Universiti Malaya.

2. Ainsworth, M. (2001). The ABC's of Internet therapy. Diakses pada $20 \mathrm{Mac} 2019$ dari

3. http://www.metanoia.org/ihmas/history.htm.

4. Akta Kaunselor 1998 (Akta 580)

5. Ajzen I. \& Fishbein, M. (1975). Belief, attitude, intention and behaviour: An introduction to theory and research. Reading: Addison Wesley.

6. Ajzen, I., \& Fishbein, M. (1980). Understanding attitudes and predicting social behavior. Englewood Cliffs, NJ: Prentice Hall.

7. Amla Salleh, Ramlan Hamzah, Norazah Nordin \& Simin Ghavifekr. (2015). Online

8. counselling using email: a qualitative study. Asia Pacific Education Review Online First(4)

9. Anthony, Kate, and DeeAnna Merz Nagel. Therapy Online: A Practical Guide. SAGE Publications Ltd, 2010.

10. Awabil, G., \& Akosah, J.C. (2018). Attitude of Ghanaian University Students Towards Online Counselling. Journal of Education and Practice, 9(11), 2222-1735.

11. Azizi Yahaya, Shahrin Hashim, Jamaludin Ramli, Yusof Boon \& Abdul Rahim Hamdan

12. (2007). Penyelidikan Menguasai Dalam Pendidikan: Teori Analisis dan Interpretasi data. Kuala Lumpur. PTS Profesional Publishing.

13. Baharom, N. (2010). Kamus Dewan Edisi Keempat. Kuala Lumpur: Dewan Bahasa \& Pustaka.

14. Bambling, M., King, R., Reid, W., \& Wegner, K. (2008). Online counselling: The experience

15. of counsellors providing synchronous single-session counselling to young people. Counselling and Psychotherapy Research, 8(2), 110-116.

16. Barak, A. (2001). Online therapy outcome studies. Diakses pada 20 Mac 2019, dari http://www.ismho.org.

17. Barak, A., Hen, L., Boniel-Nissim, M. and Shapira, N. (2008) 'A comprehensive review 
18. and a meta-analysis of the effectiveness of internet-based psychotherapeutic interventions. Journal of Technology in Human Services, 26, pp. 109-60.

19. Bato, John \& Marcial, Dave. (2016). Students' Attitudes Towards The Development Of An Online Guidance Counseling System. Information Technologies and Learning Tools. 56. 40. 10.33407/itlt.v56i6.1498.

20. Bloom, J..W. (1998) The ethical practice of Webcounselling. British Journal of Guidance and Counselling, 26(1), 53-59.

21. Bryman, A. (2008) Social research methods. 3rd Edition. Oxford University Press., New York.

22. Busseri, M. A., \& Tyler, J. D. (2003). Interchangeability of the working

23. alliance inventory and working alliance inventory, short form. Psychological Assessment, 15, 193197.

24. Chaudron, S. (1998). "Shrink-wrap". Industry Week. Vol. 247 Issue 3: 76-78.

25. Chester, A. \& Glass, C. (2006). Online Counselling: A descriptive analysis of

26. therapy services on the Internet. British Journal of Guidance \& Counselling, 34 (2), 145-160.

27. Chua, Y. P. (2006). Kaedah dan Statistik Penyelidikan. Kuala Lumpur: McGraw Hill.

28. Creswell, J. W. (2005). Educational research: Planning, conducting, and evaluating quantitative and qualitative research. Upper Saddle River, NJ: Pearson.

29. Creswell, J. W. (2008). Educational research: Planning, conducting, and evaluating

30. quantitative and qualitative research (3rd ed.). Upper Saddle River, NJ: Pearson Education, Inc.

31. Creswell, J. W. (2009). Research Design: Qualitative, Quantitative, and Mixed

32. Methods Approaches (3rd ed.). Thousand Oaks, CA: Sage Publications.

33. Davis, F. D. (1989). Perceived usefulness, perceived ease of use, and user acceptance of information technology. MIS Quarterly, 13(3), 319-340.

34. Davis, F. D., Bagozzi, R. P., \& Warshaw, P. R. (1989). User acceptance of computer

35. technology: A comparison of two theoretical models. Management Science, 35(8), 982-1003.

36. Derek Richards. (2009). Features and benefits of online counselling: Trinity

37. College online mental health community. British Journal of Guidance and Counselling 37(3):231 - 242

38. Derrig-Palumbo, K. and Zeine, F. (2005) Online Therapy: A Therapist's Guide

39. to Expanding your Practice, New York, Norton.

40. Faye Mishna, Marion Bogo, Jami-Leigh Sawyer. (2013). Cyber Counseling:

41. Illuminating Benefits and Challenges. Springer Science+Business Media New York 2013.

42. Finn, J., \& Bruce, S. (2008). The LivePerson model for delivery of etherapy services: A case study.Journal of Technology in Human Services, 26, 282-309.

43. Fraenkel, J.R., and Wallen, N.E. 1996. How to Design and Evaluate Research. USA : Mc. Fraw-Hill Inc.

44. Griffith, M., \& Cooper, G. (2003). Online therapy: Implication for problem gamblers and clinicians. British Journal of Guidance and Counselling, 31(1), 113-135.

45. Glueckauf, R. L., Fritz, S. P., Ecklund-Johnson, E. P., Liss, H. J., Dages, P., \&

46. Carney, P. (2002). Videoconferencing-based family counseling for rural teenagers with epilepsy: Phase 1 findings. Rehabilitation Psychology, 47(1), 49.

47. Gay, L. R., \& Airasian (2003). Educational Research: Competencies for Analysis and Applications (7th ed.). Upper Saddle River, NJ: Merrill/Prentice Hall.

48. Hall, P. (2004). Online psychosexual therapy: A summary of pilot study

49. findings. Sexual and Relationship Therapy, 19(2), 167-178.

50. Haberstroh, S., Duffey, T. D, Evans, M., Gee, R., \& Trepal, H. (2007). The experience

51. of online counseling. The Journal of Mental Health Counseling, 29(3), 269282.

52. Ibrahim Tanrikulu. (2009). Counselors-in-training students' attitudes towards online ounselling. Procedia - Social and Behavioral Sciences 1(1):785-788

53. Hellriegel, D., Jackson, S.E., \& Slocum, J.W. (1999). Management (8th ed.).

54. Cincinnati, Ohio: South-Western College

55. Kamus Dewan. Edisi keempat, Kuala Lumpur: Dewan Bahasa dan Pustaka, 2007

56. Kerlinger, F.N. (1973). Foundation of Behavioural Research. New York. Holt.

57. Rinehand and Hinston

58. Kolog, E. A., Sutinen, E., \& Vanhalakka-Ruoho, M. (2014). E-counselling implementation:Students' life stories and counselling technologies in perspective. International Journal of Education and Development using Information and Communication Technology, 10(3), 32.

59. Kraus, R., Zack, J. and Sticker, G. (eds) (2004) Online Counseling: A Handbook for Mental Health Professionals, San Diego, CA, Elsevier Academic Press.

60. Krejcie, R.V. and Morgan, D.W. (1970) Determining Sample Size for 
61. Research Activities. Educational and Psychological Measurement, 30, 607-610.

62. Larsen, L. M. (1998). The social cognitive model of counselor training. The

63. Counseling Psychologist, 26, 219-273.

64. Laszlo, J.V., Esterman,G., \& Zabko, S. (1999). Therapy over the internet?

65. Theory, research \& finances. Diakses pada $20 \quad$ Mac 2019 dari http://www.ismho.org/issues/therapy internet.htm

66. Lawrence (1998) dalam Murphy, L.J. et al (1998). "When Writing Helps to Heal:E- Mail as therapy". British Journal of Guidance \& Counselling. Vol26: 21-33.

67. Liebert, T., Archer, J. and Munson, J. (2006) 'An exploratory study of client perceptions of internet counselling and the therapeutic alliance', Journal of Mental Health Counselling,28, pp. 69-84.

68. Lily Mastura Harun (2000, 27-28 Oktober). 'E-mail therapy: a case study'. Kertas kerja dibentang dalam Seminar Education and ICT in the new millennium, Park Royal, Kuala Lumpur.

69. Lily Mastura Harun, Zaida Nor Zainudin, Ramlan Hamzah (2001, 27-28

70. Ogos). E-Counselling: The willingness to participate. International Education Conference, PJ Hilton, Petaling Jaya.

71. Lu, J., Yu, C., Liu, C., \& Yao, J. E. (2003). Technology acceptance model for

72. wireless Internet. Internet Research: Electronic Networking Applications and Policy, 13, 206-222.

73. Lunt, P. T. (2004). Adolescents' willingness to utilize online counseling. Unpublished Doctorate Thesis. Virginia Polytechnic Institute and State University, Virginia.

74. McMurtry, S. L., \& Hudson,W.W. (2000). The client satisfaction inventory:

75. Results of an initial validation study. Research on Social Work Practice, 10, 644-663.

76. Mohd Majid Konting (1990). "Kaedah Penyelidikan Pendidikan.” Kuala

77. Lumpur: Dewan Bahasa Dan Pustaka.

78. Mohd Majid Konting (1994 ), "Kaedah Penyelidikan Pendidikan.” Kuala

79. Lumpur: Dewan Bahasa dan Pustaka

80. Mohd Nor Mamat. (2000). Era Maklumat dari Perspektif Islam. Pemikir, Jan-Mac 2000, 15-26.

81. Mohd Yusri Ibrahim. 2010. Analisis Data Penyelidikan: Untuk Pendidikan \&

82. Sains Sosial. Kuantan: Bandar Ilmu.

83. Mohd Sobhi Ishak, Azahar Kasim, Awan Ismail \& Norsiah Abdul Hamid.

84. (2018). Teori Dalam Penyelidikan Media: Analisis Tahun 2002 Hingga 2012. eBangi Vol. 13, No. 1 (2018), 008 ISSN: 1823-884x

85. Murphy, L. J. and Mitchell, D. L. (1998) 'When writing helps to heal: E-mail

86. as therapy',British Journal of Guidance and Counselling, 26, pp. 21-32.

87. Notoatmodjo, Soekidjo. 2003. Pendidikan Dan Perilaku Kesehatan. Rineka

88. Cipta. Jakarta.

89. Oravec, J.A. (2000). Internet and computer technology hazards: perspective for family counseling. British Journal of Guidance \& Counselling, 28(3), 309-324.

90. Reynolds, D. J., Stiles, W. B. and Grohol, J. M. (2006) 'An investigation of

91. session impact and alliance in internet based psychotherapy: Preliminary results', Counselling and Psychotherapy, 6, pp. 164-8.

92. Robbins, Stephen P. (2002), Gelagat Organisasi, Abdul Razak Ibrahim \&

93. Ainin Sulaiman (terj.). T.T.P: San Diego State University, h.100 .

94. Robson, C. (2011). Real world research: A resource for social-scientists and

95. practitioner- researchers. 3rd edition. Oxford: Blackwell Publishing.

96. Robson, D. \& Robson, M. (2000). Ethical issues in internet counseling. Counselling Psychology Quarterly, 13(3), 249-257.

97. Rochland, A., Beretvas, N. and Zack, J. (2004) 'The online and face-to-face

98. counselling attitudes scales: A validation study', Measurement and Evaluation in Counselling and Development, 37, pp. 95-111.

99. Rochlen, A. B., Zack, J. S., \& Speyer, C. (2004). Online therapy: Review of relevant

100.definitions, debates, and current empirical support. Journal of clinical psychology, 60(3), 269-283.

101.Rosnee Ahad, Mohamad Zaid Mustafa, Suhaimi Mohamad, Nur Hanim Saadah Abdullah, Mohd Norazmi Nordin (2021). Work Attitude, Organizational Commitment and Emotional Intelligence of Malaysian Vocational College Teachers. Journal of Technical Education and Training Vol. 13 No. 1 (2021): 15-21.

102.Rummell, C. M., \& Joyce, N. R. (2010). So wat do u want to work on 2 day?

103. The ethical implications of online counseling. Ethics \& Behavior, 20(6), 482-496.

104.Sabrina Cipolletta \& Damiano Mocellin. (2018). Online counseling: An exploratory survey of Italian psychologists' attitudes towards new ways of interaction. Psychotherapy Research 28(6):1-16

105.Sampson, Jr., J. P., Kolodinsky, R. W., \&Greeno, B. P. (1997). Counseling on 
106.the information highway: Future possibilities and potential problems. Journal of Counseling \& Development, 75, 203-212.

107.Sander, F. M. (1996). Couple group therapy conducted via computer-mediated

108.communication: A preliminary case study. Computers in Human Behavior, 12(2), a. 301-312.

109.Sanders, P., \& Rosenfield, M. (1999). Counselling at a distance: Challenges and new a. initiatives. British Journal of Guidance \& Counselling

110.Saparwati, Mona. 2012. Pengalaman Kepala Ruang Dalam Mengelola Ruang

111.Rawat Inap Di RSUD Ambarawa. (Jurnal) Prosiding Konferensi Nasional PPNI Jawa Tengah 2013

112.Sekaran, U. (2000). Research Methods for Business: A Skill Building

113.Approach (3rd Edn). New York: John Wiley \& Sons.

114. Sule Bastemur \& Erdal Bastemur. (2015). Technology Based Counseling:

115.Perspectives of Turkish Counselors. Procedia - Social and Behavioral Sciences, Volume 176, 20 February 2015, Pages 431-438

116. Tang Chee Yee. (1989). Bimbingan dan kaunseling: Untuk sekolah rendah dan

117.menengah. Kuala Lumpur: Kumpulan Budiman Sdn. Bhd.

118.Tannous A. (2017). Perceptions towards online counseling among University

119. of Jordan students. Published by Canadian Center of Science and Education

120.Trait, A. (1999). Face-to-face and at a distance: The mediation of guidance and counselling through the new technologies. British Journal of Guidance \& Counselling. 27(1), 113-123.

121.Tuti Iryani Mohd Daud, Zasmani Shafiee, Wan Salwina Wan Ismail, Nik Ruzyanie Nik Jaafar, Abqariyah Yahya \& Zaharah Sulaiman. (2005). The Pattern Of Help Seeking Behaviour Using The Internet Among Adoloscent

122.Van de Luitgaarden, G., \& van der Tier, M. (2016). Establishing working

123.relationships in online social work. Journal of Social Work, 1468017316654347.

124.Vijay Bhuria R.K Dixit. (2014). Student Satisfaction Of Online Counseling -

125.A Descriptive Analysis. International Journal of Advanced Research in Management and Social Sciences, ISSN: 2278-6236

126.We Are Social - Digital Report (2018). World's Internet Users Pass The 4

127.Billion Mark. Di akses pada 18 Mac 2019, dari https://digitalreport.wearesocial.com/

128.Wong, K. P., Bonn. G., Tam, C.L., Wong, C.P. (2018). Preferences for Online and/or

129.Face-to-face Counselling among University Students in Malaysia. Frontiers in Psychology, 9(64), 0900064

130. Young, K,S. (2005). An empirical examination of client attitudes towards

131.online counseling. Cyber Psychology \& Behavior, 8 (2), 172-177.

132.Zaida Nor bt Zainudin (2006). Perhubungan Menolong Secara Maya: Satu

133.Penelitian. Kertas kerja dibentang dalam Persidangan Lembaga Kaunselor, Hotel Legend, Kuala Lumpur.

134.Yogesh Hole et al 2019 J. Phys.: Conf. Ser. 1362012121

135.Zaida Z \& Lily Mastura Hj H. (2006). Perkhidmatan Menolong Secara Maya-

136. Satu Penelitian. National Counseling Seminar 2006, Hotel Legend, Kuala Lumpur.

137.Zainah, A. Z., Rohany, N., \& Fatimah, Y. (2010). Perceptions towards online

138.counseling among counselors in Malaysia. Procedia Social and Behavioral Sciences, 5(2010) 585-589, 1877-0428 @ 2010 Published by Elsevier Ltd.

139.Zainudin, Z.N, Yusop, Y.M, Hassan, S.A, Alias B.S. (2019). The Effectiveness of Cybertherapy for the Introvert And Extrovert Personality Traits. Malaysian Journal of Medicine and Health Sciences. 15(SUPP1): 105-109

140.Zikmund, W.G. (2003), "Business Research Method", $7^{\text {th }}$ edn., Cengage

141.Learning, India. 